\title{
Contrast sensitivity assessment in different age group in medium and high spatial frequency
}

\author{
Avaliação da função de sensibilidade ao contraste em diferentes \\ faixas etárias nas médias e altas frequências espaciais
}

Reinaldo de Oliveira Sieiro', Letícia Maria Coelho², Patrícia Castro Vilas Boas³ ${ }^{3}$ Samira Chalub Fonseca³ ${ }^{3}$ Sheila Rodrigues Souza ${ }^{3}$, Thaís de Paula Guimarães ${ }^{3}$

\begin{abstract}
Objective: To compare contrast sensitivity in different age groups: 20 to 25, 40 to 45 and above 60 years old. Methods: We performed a cross sectional study with individuals of different ages, with visual acuity better than 20/25, without eye disease and without prior eye surgery. Visual acuity was measured by Snellen test and contrast sensitivity was evaluated by OPTEC 3500P® equipment. Statistical analysis was performed using Wilcoxon test, considering a 95\% confidence interval. Results: Compared to patients between 20 and 25 years old, patients between 40 and 45 years old did not presented decreased contrast sensitivity in any of evaluated frequencies. When compared to patients between 40 and 45 years old, patients over 60 years old presented decrease in contrast sensitivity at frequencies of 6,0 to 12,0 cpg in diurnal mode and 3,0 to 18,0 cpg in nocturnal mode. But when compared to patients between 20 and 25 years, patients older than 60 years old showed contrast sensitivity decreased in the frequencies of 3,0 to $18 \mathrm{cpg}$ in diurnal mode and at all frequencies in nocturnal mode. Conclusion: Contrast sensitivity seems to decrease with age, after 45 years old, especially in middle and high spatial frequencies. This condition may affect reading, direction and mobility, as well as other daily activities.
\end{abstract}

Keywords: Contrast sensitivity; Visual perception; Vision screening; Aging; Vision disorders

\section{ReSUMO}

Objetivo: Comparar a sensibilidade ao contraste nas faixas etárias de 20 a 25, 40 a 45 e acima de 60 anos de idade. Métodos: Realizouse um estudo transversal com indivíduos de diferentes idades, com acuidade visual superior a 20/25, sem doença ocular e sem cirurgia oftalmológica prévia. A acuidade visual foi medida pelo teste de Snellen e, a sensibilidade ao contraste, pelo aparelho OPTEC $3500 \mathrm{P} \circledast$. A análise estatística foi realizada pelo teste de Wilcoxon, considerando um intervalo de confiança de $95 \%$. Resultados: Em relação aos pacientes de 20 a 25 anos, os de 40 a 45 anos não apresentaram diminuição significativa da sensibilidade ao contraste em nenhuma das frequências espaciais avaliadas. Comparando os pacientes acima de 60 anos aos de 40 a 45 anos, houve diminuição da sensibilidade ao contraste nas frequências de 6,0 a $18,0 \mathrm{cpg}$ no modo diurno e de 3,0 a $18,0 \mathrm{cpg}$ no noturno. Já quando comparados aos de 20 a 25 anos, os pacientes maiores de 60 anos mostraram diminuição nas frequências de 3,0 a 18 cpg no modo diurno e em todas as frequências no modo noturno. Conclusão: A função de sensibilidade ao contraste parece diminuir com a idade, após os 45 anos, principalmente nas médias e altas frequências espaciais. Isso pode impactar na leitura, na direção e na mobilidade, dentre outras atividades diárias.

Descritores: Sensibilidades de contraste; Percepção visual; Seleção visual; Envelhecimento; Transtornos da visão

\footnotetext{
${ }^{1}$ Faculdade de Ciência Médicas de Minas Gerais, Belo Horizonte, MG, Brazil.

2 Setor de Urgências e Setor de Córnea e Doenças Externas, Hospital São Geraldo, Hospital das Clínicas, Universidade Federal de Minas

Gerais, Belo Horizonte, MG, Brazil.

${ }^{3}$ Faculdade de Ciência Médicas de Minas Gerais, Belo Horizonte, MG, Brazil.

Study carried out at Faculdade de Ciência Médicas de Minas Gerais, Belo Horizonte, MG, Brazil.

The authors declare no conflicts of interests.

Received for publication 02/03/2016 - Accepted for publication 12/05/2016
}

Rev Bras Oftalmol. 2016; 75 (4): 296-9 


\section{INTRODUCTION}

$\mathbf{S}$ ight is one of the most important human senses, featuring several functions, like visual acuity, contrast sensitivity, visual field, motion perception, color perception ${ }^{1}$.

Although it is one of the most practiced ophthalmic routines, visual acuity is only one of the visual functions. Whereas its measurement consists on the identification of the smallest optotype in maximum contrast condition (perfect sight), contrast sensitivity tests seek to evaluate the daily vision ${ }^{2}$. This is the so-called functional vision, and reflects vision in real situations with the perception of images of different sizes and different levels of contrast ${ }^{3,4}$.

The ability to detect low-contrast objects is an important aspect in the visual performance, and is directly related to the ability to perform everyday tasks, such as driving, reading, walking, recognizing faces and using the computer. Evidence also suggests that contrast sensitivity can help detect and monitor diseases such as glaucoma, cataract, keratoconus, macular degeneration, diabetic retinopathy and optic neuropathy. Due to providing more information about the visual quality, it is widely used in the statement and evaluation of results of surgeries and other eye treatments, and also in the evaluation of patients with low visão $0^{5,6}$.

Not many researches were published so far evaluating the contrast sensitivity curve in different ages, and work was published evaluating it in the Brazilian population. The aim of this study is to compare the contrast sensitivity in the age groups of 20 to 25 years, 40 to 45 years, and over 60 years in a population in Brazil.

\section{MethodS}

This work is a cross-sectional study with individuals chosen at random and who voluntarily underwent the ophthalmologic tests proposed.

The ophthalmologic tests were performed on 118 eyes, 43 eyes being in the range from 20 to 25 years, 42 eyes in the range from 40 to 45 years, and 33 eyes in the range above 60 years. The sample was chosen at random and evaluated by the $\mathrm{X}^{2}$ test in order to verify its significance.

This study included only individuals with corrected visual acuity equal to or above 20/25, with normal ophthalmologic exam, without any eye disease, except ametropia (corrected), and no history of ocular surgery.

The visual acuity was measured by the Snellen test, with the best optical correction and by the same examiner.

The contrast sensitivity function was measured by means of the apparatus OPTEC 3500P (Stereo Optical Co., Inc. USAÒ), again by the same examiner. This equipment employs the Functional Acuity Contrast Test - FACT protocol, considered one of the most suitable for clinical studies ${ }^{4,6}$. Its measurements are made by reading sine bars of high quality in the spatial frequencies of $1.5 ; 3.0 ; 6.0 ; 12.0$ and 18.0 cycles per degree (cpd). The bars are arranged in a gray background, with constant average illumination in an inclination of 15 degrees to the right, 0 degree (vertical) or 15 degrees to the left. Nine different levels of contrast are evaluated in each spatial frequency, in a progression of 0.15 logarithmic unit. The daytime basal (photopic), nighttime basal (mesopic) and nighttime with glare modes were tested. Once the calibration of the equipment is automatic, no adjustments are required by the operator. The equipment itself simulates photopic $\left(85 \mathrm{~cd} / \mathrm{m}^{2}\right)$ and mesopic (3 $\mathrm{cd} / \mathrm{m}^{2}$ ) conditions, besides mesopic with glare during the exam.

The statistical analysis of the data obtained was made using non-parametric Wilcoxon test in order to test whether the variable age influences the contrast sensitivity function. The results were not considered significant when $\mathrm{p}<0.05$, therefore representing a $95 \%$ confidence interval.

As it was an epidemiological study, patients were not identified and signed the informed consent (TCLE) to participate in the research. All provisions of ethics in research have been observed, in accordance with resolution 196/96 of Conselho Nacional de Saúde/Ministério da Saúde (CNS/MS). The present work has been approved by the Research Ethics Committee of Faculdade de Ciências Médicas de Minas Gerais (CAAE: 47164315.8.0000.5134).

\section{Results}

When comparing patients aged from 20 to 25 years with those aged from 40 to 45 years in all modes and in all spatial frequencies, there was no significant difference in the contrast sensitivity function (Table 1).

Table 1

Significance of contrast sensitivity variation (p) between the age groups from 20 to 25 years and from 40 to 45 years in all spatial frequencies and in all modes

\begin{tabular}{llllll}
\hline Frequencies (cpd) & $\mathbf{1 . 5}$ & $\mathbf{3 . 0}$ & $\mathbf{6 . 0}$ & $\mathbf{1 2 . 0}$ & $\mathbf{1 8 . 0}$ \\
\hline $\begin{array}{l}\text { Daytime } \\
\text { Basal }\end{array}$ & 0.084 & 0.223 & 0.418 & 0.620 & 0.083 \\
$\begin{array}{l}\text { Nighttime } \\
\begin{array}{l}\text { Basal } \\
\text { With }\end{array} \\
\text { Glare }\end{array}$ & 0.065 & 0.130 & 0.381 & 0.342 & 0.174 \\
& 0.103 & 0.153 & 0.679 & 0.116 & 0.192 \\
\hline
\end{tabular}

When age group from 40 to 45 years was compared to the age group above 60 years, there was a significant decrease in the contrast sensitivity function in patients over 60 years in the spatial frequencies of $6.0 \mathrm{cpd} ; 12.0 \mathrm{cpd}$ and $18 \mathrm{cpd}$ in daytime basal mode, in all frequencies in the nighttime basal mode, and in the frequencies of $3.0 \mathrm{cpd} ; 6.0 \mathrm{cpd} ; 12.0 \mathrm{cpd}$ and $18 \mathrm{cpd}$ in the nighttime basal mode with glare (Table 2).

Table 2

Significance of contrast sensitivity variation (p) between the age groups from 40 to 45 years and 60 years or above in all spatial frequencies and in all modes

\begin{tabular}{llcccc}
\hline Frequencies (cpd) & $\mathbf{1 . 5}$ & $\mathbf{3 . 0}$ & $\mathbf{6 . 0}$ & $\mathbf{1 2 . 0}$ & $\mathbf{1 8 . 0}$ \\
\hline $\begin{array}{l}\text { Daytime } \\
\text { Basal }\end{array}$ & 0.156 & 0.069 & 0.000 & 0.000 & 0.003 \\
$\begin{array}{l}\text { Nighttime } \\
\text { Basal }\end{array}$ & 0.038 & 0.001 & 0.001 & 0.000 & 0.000 \\
$\begin{array}{l}\text { With } \\
\text { Glare }\end{array}$ & 0.011 & 0.001 & 0.000 & 0.000 & 0.000 \\
\hline
\end{tabular}


When age group from 20 to 25 years was compared to the age group above 60 years, there was a significant decrease in the contrast sensitivity in patients over 60 years in the spatial frequencies of $3.0 \mathrm{cpd} ; 6.0 \mathrm{cpd} ; 12.0 \mathrm{cpd}$ and $18 \mathrm{cpd}$ in daytime basal mode, and in all frequencies in the nighttime basal mode and in the nighttime basal mode with glare (Table 3 ).

Table 3

Significance of variation of sensitivity to contrast (p) between the ages 20 to 25 years and 60 years or more, in all spatial frequencies, and in all modes

\begin{tabular}{|c|c|c|c|c|c|c|}
\hline & Frequencies (cpd) & 1.5 & 3.0 & 6.0 & 12.0 & 18.0 \\
\hline \multirow{6}{*}{ 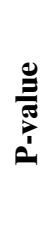 } & Daytime & & & & & \\
\hline & Basal & 0.008 & 0.036 & 0.001 & 0.001 & 0.000 \\
\hline & Nighttime & & & & & \\
\hline & Basal & 0.002 & 0.000 & 0.000 & 0.000 & 0.000 \\
\hline & With & & & & & \\
\hline & Glare & 0.000 & 0.000 & 0.003 & 0.000 & 0.000 \\
\hline
\end{tabular}

In the three age groups, the highest contrast sensitivity values occurred in the middle frequencies, i.e., $3.0 \mathrm{cpd}$ and 6.0 cpd, allowing the construction of a contrast sensitivity curve in the shape of inverted "U" in all of them (Graphs 1,2 and 3).

\section{Graph 1}

Average contrast sensitivity in the three age groups, at all frequencies, in the basal daytime mode (photopic).

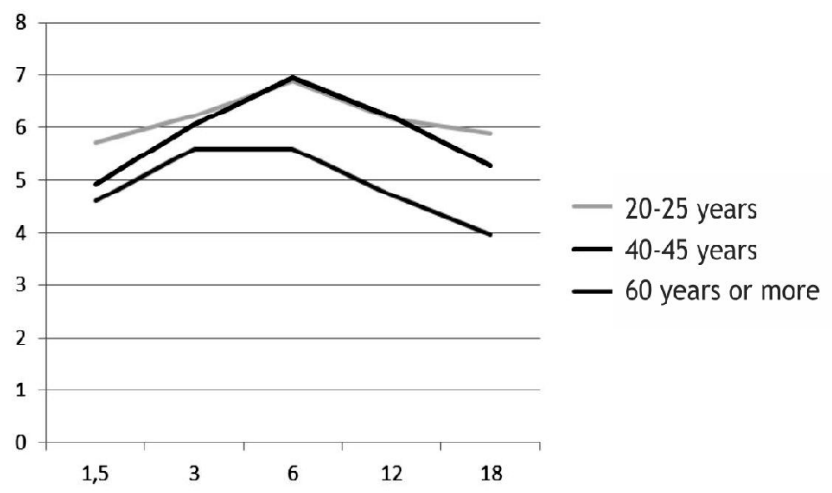

Graph 2

Average contrast sensitivity in the three age groups, at all frequencies, in the basal nighttime mode (mesopic).

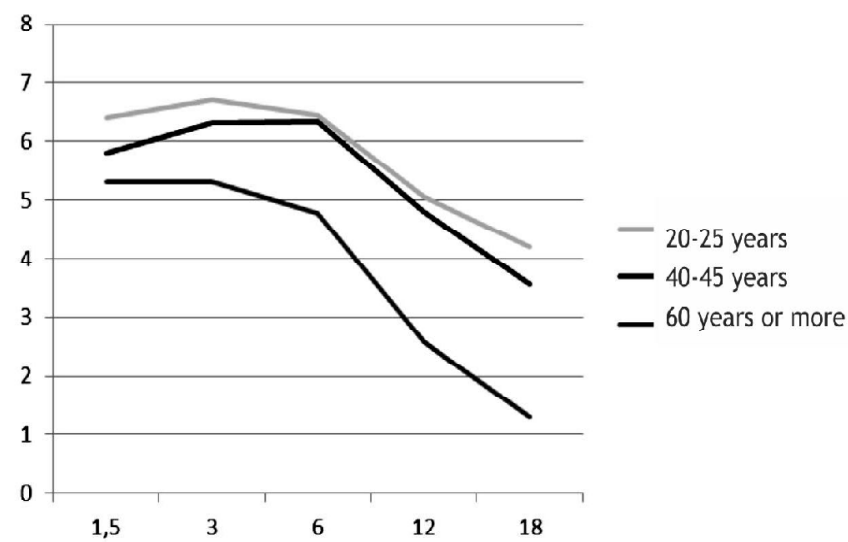

Graph 3

Average contrast sensitivity in the three age groups, at all frequencies, in the basal nighttime with glare.

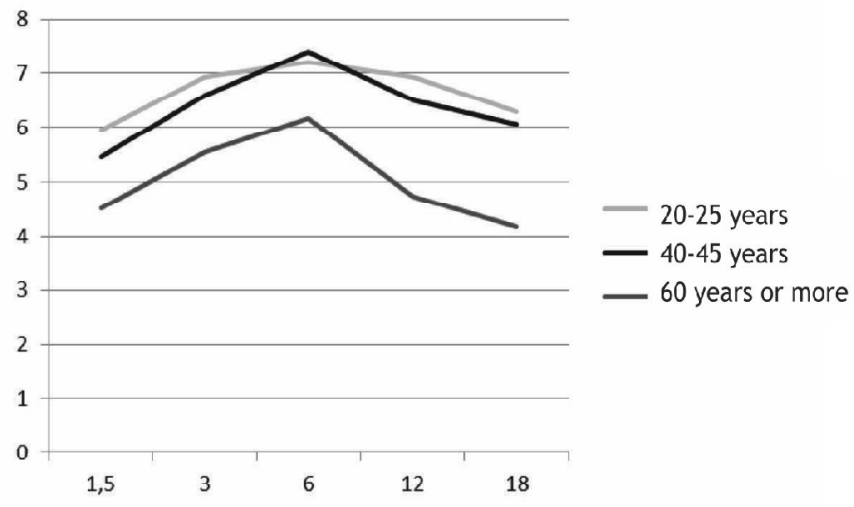

\section{Discussion}

With the growing aging of the population, it is essential to identify the visual limitations related to age, as well as their impact on performance of daily activities by the elderly ${ }^{7,8}$.

The contrast sensitivity function is considered an important aspect of the visual performance and the ability to perform daily tasks $^{3,4}$, and seemed to decrease with aging, when patients were divided into different age groups.

The lack of significant difference observed in the contrast sensitivity function among patients aged from 20 to 25 years and those aged from 40 to 45 years was already expected, since the loss of contrast sensitivity seems to happen from 45 years ${ }^{7,9}$.

But the difference noted among patients from 40 to 45 years and aged 60 years and above, especially in medium and high spatial frequencies, reinforces the findings of other authors ${ }^{9-11}$.

The differences became even more evident when we compared the patients aged from 20 to 25 years and those in the age group of 60 years and above, as they were considered extreme old.

Several studies show a worsening of contrast sensitivity in medium and high spatial frequencies in photopic conditions with aging ${ }^{9,12-14}$. The impairment of frequency of $6.0 \mathrm{cpd}$ is particularly important because this is the most often required frequency in daily activities, and therefore it is called functional vision.

Cataracts and senile changes of the retina change the contrast sensitivity even in their initial stages ${ }^{15,16}$. Thus, studies differ in the magnitude of sensitivity loss to contrast with age, since the density variations of the crystalline and the retinal agerelated changes vary in these studies. In the present study, patients showed no clinically significant cataract.

The worsening in the contrast sensitivity with age may also be due to neural factors like the reduction of retinal illuminance by senile miosis ${ }^{17}$, or due to the reduction of ganglion cell density in the retina, or due to optic factors such as the increase of highorder aberrations which can reduce the image contrast ${ }^{18}$.

The impact of contrast sensitivity loss in the routine of the elderly is not well known. Some authors suggest that these differences cannot be of clinical significance ${ }^{7}$.

However, the complaint of visual impairment to read under low light is common in the elderly ${ }^{19}$, as well as the change of habit like avoiding to drive at night and the increased risk of collisions falls ${ }^{22,23}$. 
The sensitivity function curve to human contrast in the shape of inverted "U" has also been observed by other researchers in all the age groups studied ${ }^{7,10}$. The present study confirmed these findings. In the daily life, the medium spatial frequencies (3.0 cpd and $6.0 \mathrm{cpd}$ ) are more used than the high frequencies (12.0 cpd and $18.0 \mathrm{cpd})$, responsible for the perception of details.

\section{Conclusion}

Although there are still few published studies, especially in recent years, assessing possible variations of the contrast sensitivity curve in the different age groups, the contrast sensitivity function seems to decrease with age after 45 years, especially in medium and high spatial frequencies.

\section{RefERENCES}

1. Rinaldo GR. Funções Visuais: Acuidade Visual. In: Schor P, et al. Óptica, refração e visão subnormal. Rio de Janeiro: Cultura Médica, 2008.

2. Oliveira F, Muccioli C, Silva LM, Soriano ES, Souza CE, Belfort Jr R. Avaliação da sensibilidade ao contraste e da estereopsia em pacientes com lente intra-ocular multifocal. Arq Bras Oftalmol. 2005; 68(4):439-43.

3. Woods Rl, Wood JM. The role of contrast sensitivity charts and contrast letter charts in clinical practice. Clin Exp Optom. 1995; 78(2):43-57.

4. Parede TR, Torricelli AA, Mukaill A, Netto MV, Bechara SJ. Quality of vision in refractive and cataract surgery, indirect measurers: review article. Arq Bras Oftalmol. 2013; 76(6):386-90.

5. Thayaparan K, Crossland MD, Rubin GS. Clinical assessment of two new contrast sensitivity carts. Br J Ophthalmol. 2007; 91:749-52.

6. Richman J, Spaeth GL, Wirostko B. Contrast sensitivity basics and a critique of currently available tests. J Cataract Refract Surg. 2013; 39:1100-1106.

7. Owsley C. Aging and vision. Vision Res. 2011; 51(13):1610-22.

8. Elliott Af, Mcgwin C Jr, Owsley C. Vision impairment among older adults residing in assisted living. J Aging Health. 2013;25(2):364-78.

9. Owsley C, Sekuler R, Siemsen D. Contrast sensitivity throughout adulthood. Vision Res. 1983; 23(7):689-99.

10. Sekuler R, Tynan P. Rapid measurement of contrast-sensitivity functions. Optom Phisiol Opt. 1977; 54:573-5.
11. Sekuler R, Hutman LP, Owsley C. Human aging and spatial vision. Science. 1980; 209:1255-6.

12. Derefeldt G, Lennerstrand G, Lundh B.. Age variations in normal human contrast sensitivity. Acta Ophthalmol (Copenh). 1979; 57(4):679-90.

13. Kline DW, Schieber F, Abusamra LC, Coyne AC. Age, the eye, and the visual channels: contrast sensitivity and response speed. J Gerontol. 1983; 38(2):211-6.

14. Elliott D, Whitaker D, Macveigh D. Neural contribution to spatiotemporal contrast sensitivity decline in healthy ageing eyes. Vision Res. 1990; 30(4):541-7.

15. Scott IU, Feuer WJ, Jacko JA. Impact of visual function on computer task accuracy and reaction time in a cohort of patients with age-related macular degeneration. Am J Ophthalmol. 2002; 133(3):350-7.

16. Elliott DB, Gilchrist J, Whitaker D. Contrast sensitivity and glare sensitivity changes with three types of cataract morphology: Are these techniques necessary in a clinical evaluation of cataract? Ophthalmic Physiol Opt. 1989; 9:25-30.

17. Loewenfeld IE. Pupillary changes related to age. In: THOMPSON HS, et al. Topics in neuroophthalmology. Baltimore: Williams and Wilkins; 1979.

18. Artal P, Guirao A, Berrio E, Piers P, Norrby S. Optical aberrations and the aging eye. Int Ophthalmol Clin. 2003; 43(2):63-77.

19. Kosnik W, Winslow L, Kline D. Visual changes in daily life throughout adulthood. J Gerontol. 1988; 43(3):63-70.

20. Gruber N, Mosimann Up, Müri Rm, Nef T. Vision and night driving abilities of elderly drivers. Traffic Inj Prev. 2013; 14(5):477-85.

21. Allan C, Coxon K, Bundy A, Peattie L, Keay L. Drive safe and drive aware assessment tools are a measure of driving-related function and predicts self-reported restriction for older drivers. J Appl Gerontol. 2015 Feb 26. pii: 0733464815570666.

22. Owsley C, Mcgwin C Jr. Association between visual attention and mobility in older adults. J Am Geriatr Soc. 2004; 52(11):1901-6.

23. Källstrand-Ericson J, Hildingh C. Visual impairment and falls: a register study. J Clin Nurs. 2009; 18(3):366-372.

\section{Corresponding author:}

Reinaldo de Oliveira Sieiro

Rua Alagoas, 1314/14 andar- Savassi - Belo Horizonte - MG ZIP Code: 30130-160.

Phone/fax (31) 3281-0001 -

E-mail: reinaldosieiro@gmail.com 